\title{
VÔLEI DE PRAIA: configurações sociais de um esporte-espetáculo de alto rendimento no Brasil
}

\author{
Marília Maciel Costa
}

Curso: Doutorado em Sociologia

Data de defesa da tese: 2 de dezembro de 2005

Orientador: Prof. Dr. Lúcio de Brito Castelo Branco

\section{Resumo}

O objetivo do estudo foi resgatar e discutir a estruturação do vôlei de praia como produção de esporte de alto rendimento no Brasil. Após situá-lo no momento da modernidade, começou-se por levantar dados do esporte ainda quando amador; em seguida, procurou-se resgatar os fatos que foram marcantes para que o esporte passasse de amador a profissional, até se chegar à realidade atual. Foram feitas análises documentais, visitas a diferentes sites, entrevistas e recortes de noticiários para proceder a uma investigação que permitisse visualizar se, de fato, o vôlei de praia representa a "cultura profissional" dentro dos novos paradigmas do esporte moderno e que processo o levou, ou não, à inserção nesse modelo.

As atenções foram concentradas no período de 1986 a 2004, por ter sido aquele o ano em que a Confederação Brasileira de Voleibol (CBV) passou a gerenciar o esporte no âmbito nacional e a exercer o monopólio. Assim, sob sua gerência, ressaltou-se, em primeiro lugar, o processo de consolidação gerencial da $\mathrm{CBV}$, por meio da criação de um departamento de vôlei de praia e de um manual normativo da sua prática no País.

A partir daí, foi importante verificar como a atuação da CBV foi incisiva na formação e na organização do Circuito Mundial, a 
maior competição internacional da modalidade. A análise da criação do Circuito Nacional, em 1991, efetivado graças ao contrato de patrocínio firmado entre a Confederação e o Banco do Brasil, foi fundamental para se perceber como ocorreu a espetacularização e a mercantilização da modalidade. Outro fato que auxiliou no conhecimento do processo foi o empenho do Brasil para tornar o vôlei de praia um esporte olímpico, o que ocorreu em 1993, potencializando o poder de decisão do País diante das principais decisões mundiais da modalidade.

Procurou-se verificar, durante o levantamento dos dados coletados, a forma e os valores que predominavam no ambiente social em que se desenvolvia essa modalidade. Para isso, foram focadas as relações que se processavam no decorrer de sua estruturação e procurou-se checar o grau de influência que elas sofreram diante das mudanças estruturais capitalistas e de novas situações conjunturais.

Concluiu-se que o vôlei de praia brasileiro, mesmo apresentando problemas inerentes à própria condição de esporte de alto rendimento, e diante das muitas adversidades que enfrenta no cenário social nacional, tem se consolidado com base nos valores ditados pelo "profissionalismo", suplantando os valores de uma cultura "amadorística" e tradicional, predominante no universo esportivo nacional.

Palavras-chave: esporte de alto rendimento, Sociologia, vôlei de praia. 